\title{
Comparative Effects of Phenformin, Metformin and Glibenclamide on Metabolic Rhythms in Maturity-Onset Diabetics
}

\author{
M. Nattrass, P. G. Todd, L. Hinks, B. Lloyd, and K. G. M. M. Alberti \\ Chemical Pathology and Human Metabolism and Division of Medicine, General Hospital, Southampton, U. K.
}

\begin{abstract}
Summary. Twelve hour metabolic rhythms have been performed on six maturity-onset diabetic subjects during successive periods of therapy with phenformin, metformin, and glibenclamide. Moderate control of blood glucose concentration was achieved with phenformin and metformin, the lowest concentrations being found with glibenclamide. Mean blood lactate concentration was grossly elevated during phenformin therapy, moderately elevated with metformin and normal during glibenclamide treatment. Similar patterns were found for the lactate/pyruvate ratio, alanine, glycerol and ketone bodies. Serum triglyceride concentrations were significantly higher during phenformin treatment than with the other two regimes. Serum insulin concentration was higher on glibenclamide than with either biguanide. Most of these effects of the biguanides could be accounted for by an inhibitory effect on hepatic gluconeogenesis. It is concluded that the use of biguanides as hypoglycaemic agents in diabetes is associated with the production of multiple metabolic abnormalities.
\end{abstract}

Key words: Phenformin, metformin, glibenclamide, blood glucose, lactate, alanine, pyruvate, ketone bodies, maturity-onset diabetes, diabetic control, gluconeogenesis, glycerol, insulin, triglycerides, growth hormone.

Three major mechanisms have been postulated to explain the hypoglycaemic action of the biguanides. They are: - inhibition of glucose and amino acid transport across the small bowel $[1,2]$; enhanced glycolysis in extrahepatic tissues [3]; and inhibition of hepatic gluconeogenesis $[4,5,6,7]$. If either of the last two mechanisms are important then changes in circulating metabolites, particularly gluconeogenic substrates, would be expected.

In diabetics during biguanide therapy elevated concentrations of blood lactate and pyruvate have been reported in fasting specimens and during an oral glucose tolerance test $[8,9]$, although some reports have failed to confirm this finding [10]. In particular, attention has been paid to the massive rises in lactate, pyruvate, and alanine concentrations which occur occasionally in patients taking phenformin or metformin who present with life-threatening lactic acidosis [11, 12, 13]. Little is known, however, of the effect of biguanides, or indeed of other oral hypoglycaemic agents, on the blood concentrations of lactate and other gluconeogenic precursors and intermediary metabolites, in stable, maturity-onset diabetics during normal life.

We have, therefore, investigated blood concentrations of intermediary metabolites in six maturityonset diabetics over a twelve hour period, during successive periods of therapy with phenformin, metformin and glibenclamide.

\section{Materials and Methods}

Six patients with maturity-onset diabetes of greater than three years duration, and without evidence of hepatic or renal disease, were studied. None had clinical evidence of diabetic complications and details of the patients are given in Table 1 . Informed consent was obtained from all patients and approval was given by the local ethical committee. Initial therapy was with phenformin spansules, $50 \mathrm{mg}$ twice daily, which was changed to metformin $500 \mathrm{mg}$ three times daily, after the first period of study. After one month of therapy with metformin, a second 
Table 1. Characteristics of patients

\begin{tabular}{llllll}
\hline Patient & Sex & Age & $\begin{array}{l}\text { Duration } \\
\text { of } \\
\text { diabetes (y) }\end{array}$ & $\begin{array}{l}\text { \% ideal } \\
\text { body } \\
\text { weight }\end{array}$ & $\begin{array}{l}\text { Other } \\
\text { drug } \\
\text { therapy }\end{array}$ \\
\hline L. C. & 9 & 52 & 4 & 141 & Navidrex K \\
G. B. & $\sigma^{7}$ & 77 & 4 & 91 & None \\
W. H. & $\sigma^{7}$ & 65 & 7 & 119 & None \\
A.C. & 9 & 62 & 2 & 148 & None \\
L. H. & $\sigma^{7}$ & 60 & 3 & 112 & None \\
E. G. & $\sigma^{7}$ & 50 & 3.5 & 121 & None \\
\hline
\end{tabular}

study was performed and therapy then changed to glibenclamide $5 \mathrm{mg}$ daily ( 5 patients) or $2.5 \mathrm{mg}$ daily (1 patient). After a further month the final study was performed.

Each study lasted for $12 \mathrm{~h}$. After an overnight fast an indwelling teflon cannula was inserted into an antecubital vein at $0800 \mathrm{~h}$. Two fasting samples were taken at $0825 \mathrm{~h}$ and $0830 \mathrm{~h}$, following which breakfast was eaten. Blood samples were taken halfhourly until $2000 \mathrm{~h}$ with lunch at $1205 \mathrm{~h}$ and dinner at $1805 \mathrm{~h}$. Snacks were given at $1005 \mathrm{~h}$ and $1505 \mathrm{~h}$. Each patient ate their normal diet, which in all cases comprised $150 \mathrm{~g}$ carbohydrate and a total of 1500 Calories.

Phenformin was administered at $0835 \mathrm{~h}$ and $1805 \mathrm{~h}$; metformin at $0835 \mathrm{~h}, 1205 \mathrm{~h}$ and $1805 \mathrm{~h}$, and glibenclamide at $0835 \mathrm{~h}$. During the study patients were encouraged to take gentle exercise between blood sampling times.

Approximately $10 \mathrm{ml}$ of free-flowing blood was taken at each sample time: $1-2 \mathrm{ml}$ for metabolite assays were mixed with $5 \mathrm{ml}$ of $5 \%(\mathrm{v} / \mathrm{v})$ perchloric acid and refrigerated immediately; $1.5 \mathrm{ml}$ blood were briefly centrifuged and the plasma frozen immediately for non-esterified fatty acid (NEFA) estimation; $2.25 \mathrm{ml}$ were mixed with $0.25 \mathrm{ml}$ Aprotinin $(2500$ i.u.) containing $25 \mu \mathrm{mol}$ of sodium ethylenediaminetetraacetate, centrifuged, and plasma separated and frozen immediately for cyclic $3^{\prime}$, 5'-AMP assay. The remaining blood was allowed to clot and the serum stored at $-20^{\circ} \mathrm{C}$ for subsequent triglyceride and hormone assays.

Glucose (hexokinase method), lactate, pyruvate, glycerol and alanine were assayed in the perchloric acid extract by modified, automated, enzymic fluorimetric methods [14].

"Total" ketone bodies refers to the sum of 3-hydroxybutyrate and acetoacetate concentrations, which were determined manually by enzymic methods [15]. Plasma NEFA were assayed by a radio-cobalt method [16], and serum triglycerides by an automated colorimetric method [17]. Serum cholesterol was estimated by an automated col- orimetric method [18]. Serum cortisol was measured using a radioactive selenium competitive protein binding method (Cortipac ${ }^{\circledR}$, Radiochemical Centre, Amersham) and plasma cyclic 3', 5'-AMP using a competitive protein binding method adapted from the Amersham kit. Serum insulin and growth hormone (HGH) were assayed by double antibody radioimmunoassay $[19,20]$.

Results are given as means \pm standard error of the mean (SEM). The twenty-four values for each metabolite or hormone over the $12 \mathrm{~h}$ period in an individual patient have been averaged and this is referred to as the $12 \mathrm{~h}$ mean. Significance has been calculated using Student's paired $t$ test for fasting samples. Significant differences between the three treatment regimes over the $12 \mathrm{~h}$ period have been sought by non-parametric methods because of the possibility of non-normal distribution. Values for each patient at each time point were ranked and the $12 \mathrm{~h}$ sum of ranks obtained. These were analysed using Friedman's test.

\section{Results}

\section{Blood Glucose}

The diurnal rhythm for blood glucose concentration during the three treatment regimes is shown in Figure 1 . There was no significant difference in blood glucose concentration during phenformin and metformin therapy at any time during the $12 \mathrm{~h}$ period, with values moderately elevated throughout the studies. During glibenclamide therapy, however, fasting values were lower than those during phenformin and metformin treatment in four and five patients respectively (Table 2).

During the whole study period, there was a highly significant decrease in blood glucose concentration during glibenclamide therapy compared with biguanide therapy $(\mathrm{p}<0.001)$. All six patients had lower $12 \mathrm{~h}$ mean values for blood glucose during glibenclamide than during phenformin, and five patients had lower values on glibenclamide than during metformin (Table 3). Overall there was no significant difference between the three treatment regimes when comparing the area under the blood glucose curve for the $2 \mathrm{~h}$ following meals. Patients on metformin, however, showed a significantly greater rise in glucose concentration $1 \mathrm{~h}$ after breakfast compared with phenformin $(\mathrm{p}<0.02)$ whilst at $11^{1 / 2}(\mathrm{p}<$ $0.01)$ and $2 \mathrm{~h}(\mathrm{p}<0.02)$ after dinner there was an enhanced glucose rise in patients on glibenclamide compared with phenformin. 


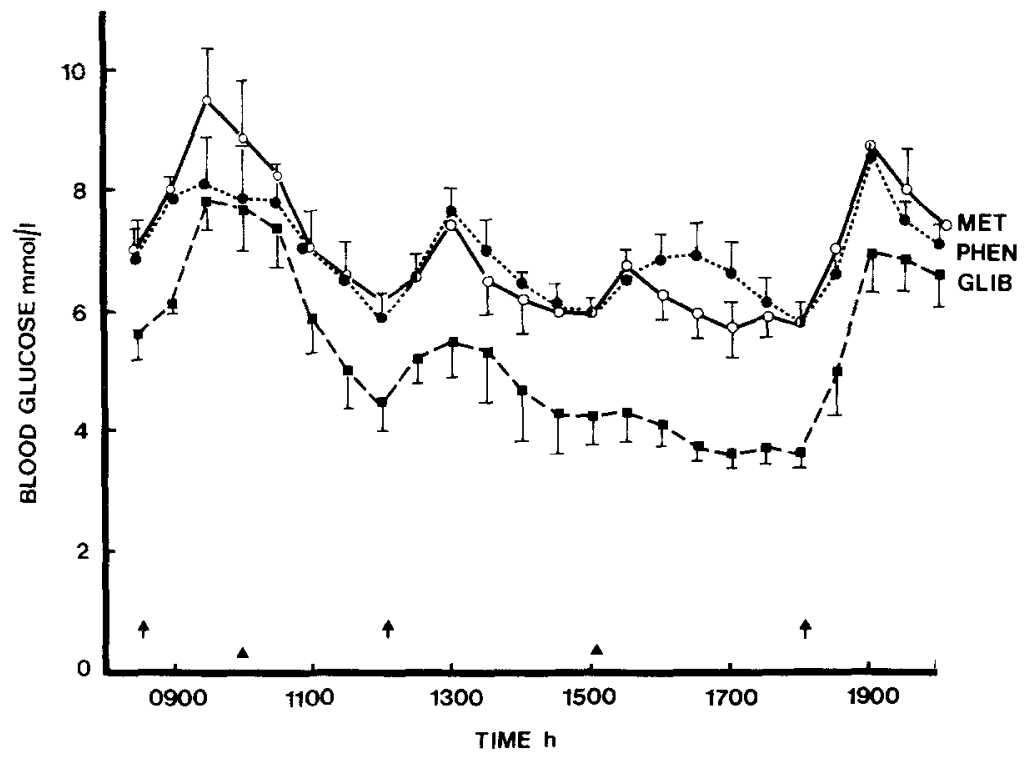

Fig. 1. Diurnal pattern of blood glucose concentration in patients taking phenformin $(\bullet \cdots \cdot)$, metformin $(\circ-0)$ or glibenclamide $(\mathbf{\square}--\mathbf{0})$. Values are given \pm SEM. Arrows indicate meal times and triangles indicate snacks

Table 2. Mean fasting metabolite and hormone concentrations ( \pm SEM) and metabolite ratios during phenformin, metformin and glibenclamide therapy. Differences between the therapies are also shown. P, phenformin; M, metformin; G, glibenclamide; *, difference not significant. Significance was assessed with the Student $t$ test

\begin{tabular}{|c|c|c|c|c|c|c|c|c|c|c|}
\hline & $\begin{array}{l}\text { Glucose } \\
\mathrm{mmol} / 1\end{array}$ & $\begin{array}{l}\text { Lactate } \\
\mathrm{mmol} / \mathrm{l}\end{array}$ & $\begin{array}{l}\text { Pyruvate } \\
\mathrm{mmol} / 1\end{array}$ & $\begin{array}{l}\text { 3-hydroxy- } \\
\text { butyrate } \\
\text { mmol/1 }\end{array}$ & $\begin{array}{l}\text { Acetoacetate } \\
\mathrm{mmol} / 1\end{array}$ & $\begin{array}{l}\text { Total } \\
\text { ketones } \\
\mathrm{mmol} / \mathrm{l}\end{array}$ & $\frac{\text { Lactate }}{\text { Pyruvate }}$ & \multicolumn{2}{|c|}{$\frac{\text { 3-hydroxybutyrate }}{\text { Acetoacetate }}$} & $\begin{array}{l}\text { Cyclic } 3^{\prime} 5^{\prime}- \\
\text { AMP nmol/1 }\end{array}$ \\
\hline Phenformin & $6.9 \pm 0.5$ & $1.17 \pm 0.16$ & $0.08 \pm 0.01$ & $0.10 \pm 0.05$ & $0.04 \pm 0.01$ & $0.14 \pm 0.06$ & $13.8 \pm 0.9$ & \multicolumn{2}{|c|}{$1.76 \pm 0.50$} & $15 \pm 4$ \\
\hline Metformin & $7.1 \pm 0.5$ & $0.92 \pm 0.14$ & $0.08 \pm 0.01$ & $0.06 \pm 0.02$ & $0.05 \pm 0.01$ & $0.10 \pm 0.03$ & $12.1 \pm 1.4$ & \multirow{2}{*}{\multicolumn{2}{|c|}{$\begin{array}{l}1.09 \pm 0.16 \\
*\end{array}$}} & $18 \pm 2$ \\
\hline P vs $M$ & & & $*$ & * & & & & & & \\
\hline Glibenclamide & $5.6 \pm 0.4$ & $0.87 \pm 0.08$ & $0.09 \pm 0.01$ & $0.03 \pm 0.01$ & $0.04 \pm 0.01$ & $0.06 \pm 0.01$ & $10.4 \pm 1.0$ & \multicolumn{2}{|c|}{$0.81 \pm 0.21$} & $11 \pm 3$ \\
\hline$P$ vs $G$ & $*$ & $*$ & $*$ & * & * & $*$ & $<0.05$ & \multicolumn{2}{|c|}{$<0.05$} & \\
\hline \multirow[t]{2}{*}{$M$ vs $G$} & $*$ & * & $*$ & * & $*$ & $*$ & $<0.05$ & $*$ & & $<0.05$ \\
\hline & $\begin{array}{l}\text { Alanine } \\
\mathrm{mmol} / \mathrm{l}\end{array}$ & $\frac{\text { Alanine }}{\text { Pyruvate }}$ & $\begin{array}{l}\text { Glycerol } \\
\mathrm{mmol} / 1\end{array}$ & $\begin{array}{l}\text { NEFA } \\
\mathrm{mmol} / 1\end{array}$ & $\begin{array}{l}\text { Trigly- } \\
\text { cerides } \\
\text { mmol/l }\end{array}$ & $\begin{array}{l}\text { Choles- } \\
\text { terol } \\
\mathrm{mmol} / \mathrm{l}\end{array}$ & $\begin{array}{l}\text { Insulin } \\
\mathrm{mU} / \mathrm{l}\end{array}$ & $\frac{\text { Insulin }}{\text { Glucose }}$ & $\begin{array}{l}\mathrm{HGH} \\
\mu \mathrm{g} / 1\end{array}$ & $\begin{array}{l}\text { Cortisol } \\
\mathrm{nmol} / 1\end{array}$ \\
\hline Phenformin & $0.47 \pm 0.03$ & $5.71 \pm 0.33$ & $0.09 \pm 0.02$ & $0.63 \pm 0.06$ & $1.1 \pm 0.1$ & $5.4 \pm 0.4$ & $5.8 \pm 1.4$ & $0.9 \pm 0.2$ & $1.95 \pm 0.75$ & $464 \pm 60$ \\
\hline Metformin & $0.39 \pm 0.03$ & $5.37 \pm 0.63$ & $0.07 \pm .0 .01$ & $10.66 \pm 0.03$ & $1.1 \pm 0.1$ & $6.2 \pm 0.6$ & $6.5 \pm 2.0$ & $1.0 \pm 0.3$ & $5.68 \pm 2.02$ & $504 \pm 77$ \\
\hline $\mathrm{P}$ vs $\mathrm{M}$ & $<0.05$ & $*$ & & * & $*$ & $*$ & $*$ & & $*$ & * \\
\hline Glibenclamide & $0.37 \pm 0.03$ & $4.44 \pm 0.50$ & $0.07 \pm 0.02$ & $0.59 \pm 0.10$ & $1.1 \pm 0.2$ & $6.3 \pm 0.8$ & $5.3 \pm 0.7$ & $1.0 \pm 0.2$ & $3.44 \pm 1.58$ & $353 \pm 30$ \\
\hline$P$ vs $G$ & $<0.05$ & $*$ & $*$ & $*$ & * & $*$ & $*$ & * & & * \\
\hline$M$ vs $G$ & $*$ & $*$ & $*$ & $*$ & * & * & $*$ & * & * & * \\
\hline
\end{tabular}

\section{Blood Lactate and Pyruvate}

There was no significant difference between fasting blood lactate concentrations during the three treatments (Table 2). In contrast, concentrations of blood lactate (Fig. 2) during the $12 \mathrm{~h}$ period were markedly elevated during therapy with both phenformin and metformin, particularly the former. During glibenclamide therapy all blood lactate levels fell within the normal range [21]. The difference in the blood lactate concentration during the three regimes was highly significant $(\mathrm{p}<0.001)$. The difference was maximal $1 \mathrm{~h}$ after lunch, with values on phenformin ranging from 1.43 to $3.03 \mathrm{mmol} / 1$ (mean $2.12 \mathrm{mmol} / \mathrm{l}$ compared with 0.53 to 1.28 (mean 0.84 $\mathrm{mmol} / \mathrm{l}$ ) on glibenclamide.

All six patients had lower $12 \mathrm{~h}$ mean values during metformin than during phenformin therapy, but in all patients the lowest $12 \mathrm{~h}$ mean values occurred on glibenclamide (Table 3).

A similar pattern was seen for blood pyruvate concentration as for blood lactate (Fig. 2; Tables 2 

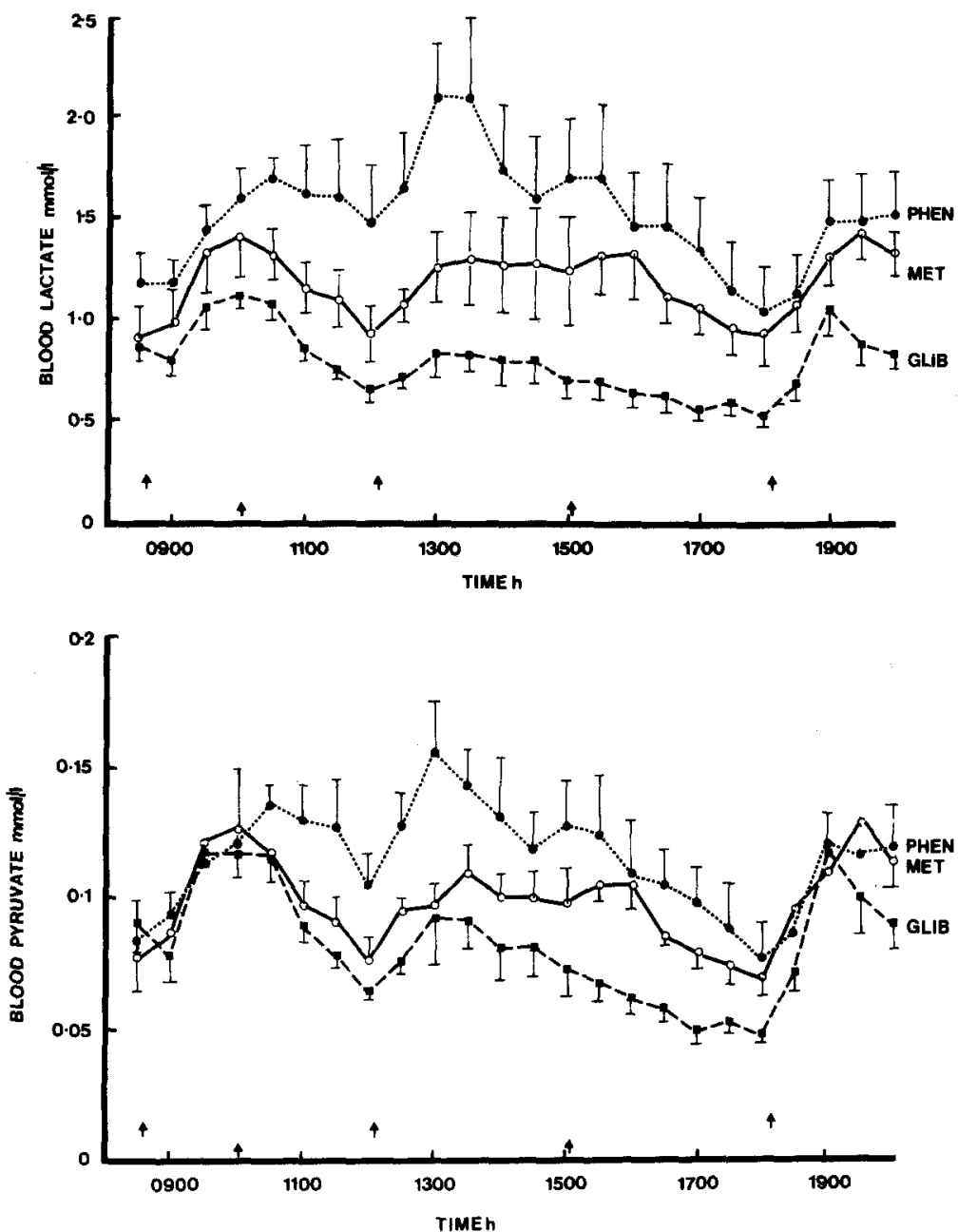

Fig. 2. Diurnal patterns of blood lactate and pyruvate concentrations in patients taking phenformin, metformin or glibenclamide. Symbols and legend as in Fig. 1

Table 3. Mean $12 \mathrm{~h}$ metabolite and hormone concentrations ( $\pm \mathrm{SEM}$ ) and metabolite ratios during phenformin, metformin and glibenclamide therapy. Significance of differences between the three therapies was assessed using the Friedman test. Apparent discrepancies between mean values and significance is due to uneven distribution of the twenty four results per patient. This has been allowed for in calculating significance. Symbols as in Table 2

\begin{tabular}{|c|c|c|c|c|c|c|c|c|c|c|c|c|c|}
\hline & $\begin{array}{l}\text { Glucose } \\
\mathrm{mmol} / 1\end{array}$ & \multicolumn{2}{|c|}{$\begin{array}{l}\text { Lactate } \\
\mathrm{mmol} / \mathrm{l}\end{array}$} & \multicolumn{2}{|c|}{$\begin{array}{l}\text { Pyruvate } \\
\mathrm{mmol} / \mathrm{l}\end{array}$} & $\begin{array}{l}\text { Total } \\
\text { ketones } \\
\text { mmol/1 }\end{array}$ & $\frac{\text { Lactate }}{\text { Pyruvate }}$ & \multicolumn{2}{|c|}{ 3-hydroxybutyrate } & \multicolumn{2}{|l|}{$\begin{array}{l}\text { Alanine } \\
\mathrm{mmol} / \mathrm{l}\end{array}$} & $\frac{\text { Alanine }}{\text { Pyruvate }}$ & $\begin{array}{l}\text { 3-hydroxy- } \\
\text { butyrate }\end{array}$ \\
\hline Phenformin & $7.0 \pm 0.2$ & 1.5 & \pm 0.22 & $0.12=$ & 0.10 & $0.14 \pm 0.04$ & $13.2 \pm 0.7$ & $1.92 \pm 0.40$ & & $0.55 \pm 0$. & & $5.2 \pm 0.4$ & $0.09 \pm 0.03$ \\
\hline Metformin & $7.0 \pm 0.4$ & 1.2 & \pm 0.16 & $0.10=$ & 0.01 & $0.10 \pm 0.01$ & $12.1 \pm 0.9$ & $0.97 \pm 0.07$ & & $0.48 \pm 0$ & & $5.1 \pm 0.3$ & $0.05 \pm 0.01$ \\
\hline $\mathrm{P}$ vs $\mathbf{M}$ & & $<0$. & 001 & $<0.0$ & & $<0.001$ & $<0.001$ & $<0.001$ & & $<0.001$ & & $<0.001$ & $<0.001$ \\
\hline Glibenclamide & $5.3 \pm 0.3$ & 0.7 & \pm 0.06 & $0.08 \pm$ & 0.01 & $0.09 \pm 0.09$ & $10.1 \pm 0.8$ & $0.86 \pm 0.18$ & & $0.35 \pm 0$. & & $4.6 \pm 0.4$ & $0.04 \pm 0.01$ \\
\hline$P$ vs $G$ & $<0.001$ & $<0$ & 001 & $<0.0$ & & $<0.001$ & $<0.001$ & $<0.001$ & & $<0.001$ & & $<0.001$ & $<0.001$ \\
\hline \multirow[t]{2}{*}{$\mathbf{M}$ vs $\mathbf{G}$} & $<0.001$ & $<0$ & 001 & $<0.0$ & & $<0.001$ & $<0.001$ & $<0.001$ & & $<0.001$ & & $<0.001$ & $<0.001$ \\
\hline & \multicolumn{2}{|c|}{$\begin{array}{l}\text { Acetoacetate } \\
\mathrm{mmol} / 1\end{array}$} & \multicolumn{2}{|c|}{$\begin{array}{l}\text { Glycerol } \\
\mathrm{mmol} / 1\end{array}$} & \multicolumn{2}{|c|}{$\begin{array}{l}\mathrm{NEFA} \\
\mathrm{mmol} / \mathrm{l}\end{array}$} & $\begin{array}{l}\text { Triglycerides } \\
\mathrm{mmol} / \mathrm{l}\end{array}$ & $\begin{array}{l}\text { Insulin } \\
\mathrm{mU} / \mathrm{l}\end{array}$ & & $\frac{\text { sulin }}{\text { ucose }}$ & \multicolumn{2}{|c|}{$\begin{array}{l}\mathrm{HGH} \\
\mu \mathrm{g} / 1\end{array}$} & $\begin{array}{l}\text { Cyclic3'5' } \\
\text { AMP nmol/1 }\end{array}$ \\
\hline Phenformin & \multicolumn{2}{|c|}{$0.05 \pm 0.01$} & \multicolumn{2}{|c|}{$0.08 \pm 0.01$} & \multicolumn{2}{|c|}{$0.54 \pm 0.05$} & $1.7 \pm 0.1$ & $16.3 \pm 3.3$ & & \pm 0.5 & \multicolumn{2}{|c|}{$1.31 \pm 0.36$} & $18 \pm 5$ \\
\hline Metformin & \multirow{2}{*}{\multicolumn{2}{|c|}{$\begin{array}{l}0.05 \pm 0.01 \\
*\end{array}$}} & \multicolumn{2}{|c|}{$0.06 \pm 0.01$} & \multicolumn{2}{|c|}{$0.55 \pm 0.03$} & $1.6 \pm 0.1$ & $18.5 \pm 2.6$ & & \pm 0.5 & \multicolumn{2}{|c|}{$1.43 \pm 0.26$} & $15 \pm 2$ \\
\hline $\mathrm{P}$ vs $\mathrm{M}$ & & & \multirow{2}{*}{\multicolumn{2}{|c|}{$\begin{array}{l}<0.001 \\
0.06 \pm 0.06\end{array}$}} & \multirow{2}{*}{\multicolumn{2}{|c|}{$0.52 \pm 0.10$}} & \multirow{2}{*}{$\begin{array}{l}<0.001 \\
1.6 \pm 0.2\end{array}$} & $<0.001$ & $*$ & & \multicolumn{2}{|c|}{$<0.01$} & $*$ \\
\hline Glibenclamide & \multicolumn{2}{|c|}{$0.05 \pm 0.01$} & & & & & & $23.5 \pm 5.1$ & & $5 \pm 0.9$ & \multicolumn{2}{|c|}{$1.35 \pm 0.22$} & $11 \pm 4$ \\
\hline$P$ vs $G$ & \multirow{2}{*}{\multicolumn{2}{|c|}{ * }} & \multicolumn{2}{|c|}{$<0.001$} & \multirow{2}{*}{\multicolumn{2}{|c|}{$\begin{array}{l}<0.001 \\
<0.001\end{array}$}} & $<0.001$ & $<0.001$ & & .001 & & .001 & $<0.001$ \\
\hline M vs $G$ & & & \multicolumn{2}{|c|}{$<0.001$} & & & & $<0.001$ & & 0.001 & & .001 & $<0.001$ \\
\hline
\end{tabular}



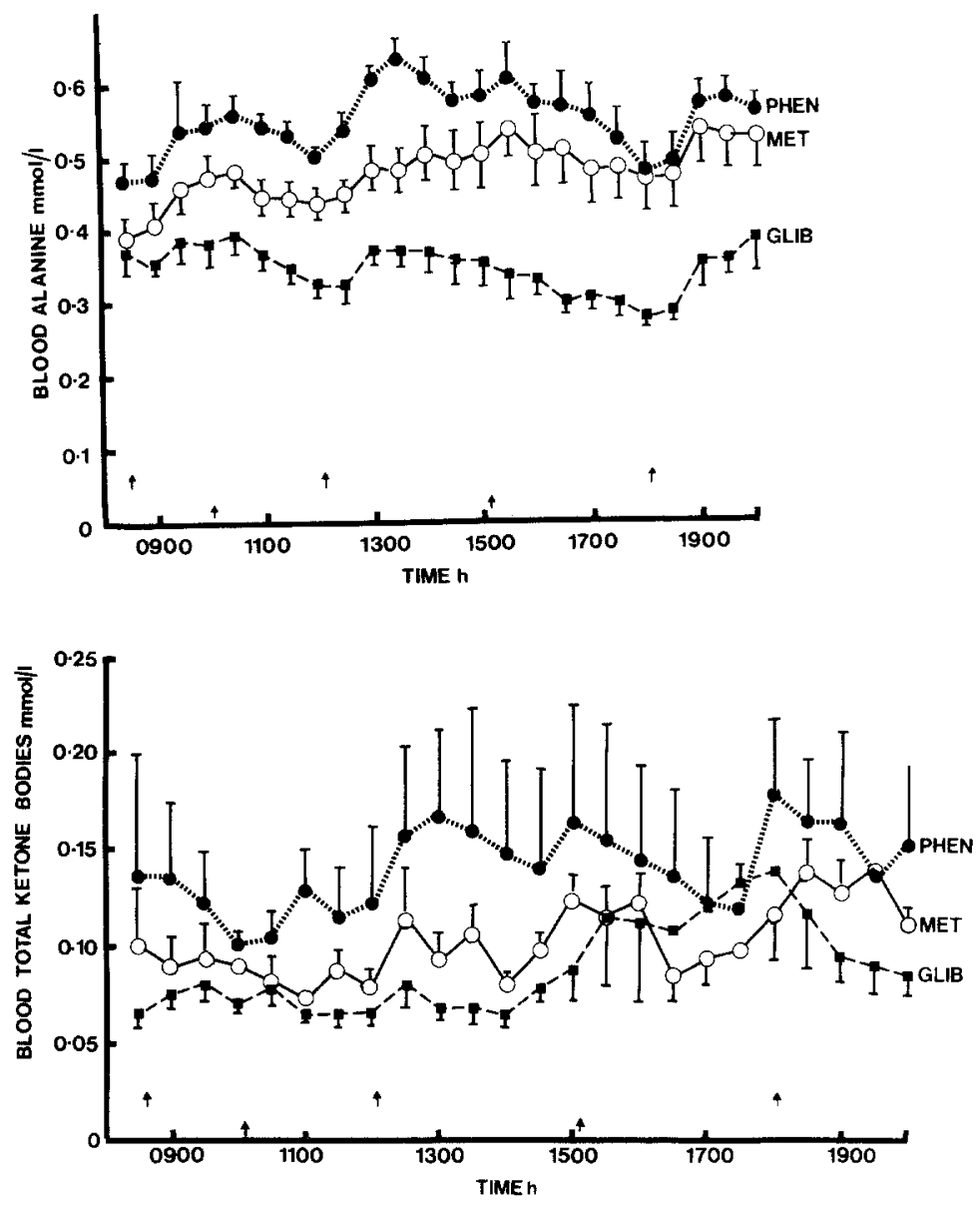

Fig. 3. Diurnal patterns of blood alanine and total ketone body concentrations in patients taking phenformin, metformin and glibenclamide. Symbols and legend as in Fig. 1 and 3). Although concentrations were elevated above the normal range during the $12 \mathrm{~h}$ periods during both biguanide therapies, the increases were proportionately less than those seen in blood lactate concentration.

\section{Blood Total Ketone Bodies}

Blood total ketone body concentrations during the $12 \mathrm{~h}$ studies showed elevated concentrations on both biguanides compared with glibenclamide (Fig. 3): the highest values, clearly above the normal range [21], were obtained with phenformin (Tables 2 and $3)$. The difference between blood total ketone bodies on the three treatments was highly significant $(\mathrm{p}<0.001)$.

The difference in total ketone body concentration was due primarily to changes in blood 3-hydroxybutyrate concentration ( $p<0.001$ ), as there was no significant difference in blood acetoacetate concentration during the three regimes.

\section{Lactate/Pyruvate $(L / P)$ Ratio and} 3-Hydroxybutyrate/Acetoacetate Ratio

The difference between $\mathrm{L} / \mathrm{P}$ ratios on the three regimes was significant $(\mathrm{p}<0.001) . \mathrm{L} / \mathrm{P}$ ratios were highest on phenformin in five of the six patients and all had their lowest $12 \mathrm{~h}$ mean value during glibenclamide (Table 3 ).

During both biguanide therapies the difference in fasting values for $\mathrm{L} / \mathrm{P}$ ratio compared with the values during glibenclamide was significant $(\mathrm{p}<$ 0.05 ) (Table 2).

Five of the six patients had lower mean values for the 3-hydroxybutyrate/acetoacetate ratio on metformin than phenformin and all had lower values on glibenclamide compared with phenformin (Table 3 ). Over the $12 \mathrm{~h}$ period the difference between the three regimes was significant $(\mathrm{p}<0.001)$.

\section{Blood Alanine and Alanine/Pyruvate Ratio}

The diurnal rhythm of blood alanine concentration is shown in Figure 3. Elevated concentrations were 
seen during therapy with both biguanides, with higher concentrations during phenformin therapy. During glibenclamide therapy there was a significant decrease $(p<0.001)$ and, during the $12 \mathrm{~h}$ period, all these concentrations lay within the normal range [21]. All six patients had lower $12 \mathrm{~h}$ mean values on glibenclamide than on either biguanide and all six had lower values on metformin than on phenformin (Table 3). The fasting concentration of blood alanine during phenformin therapy was above the fasting concentration found on both metformin and glibenclamide ( $\mathrm{p}<0.05$ for both) (Table 2).

As with blood lactate concentration the increase in blood alanine concentration during biguanide therapy was proportionately greater than that seen in blood pyruvate concentration, resulting in a significant increase in the blood alanine/pyruvate ratio ( $p<0.01$ for phenformin and metformin; $p<0.001$ for biguanides and glibenclamide) (Table 3 ).

\section{Blood Glycerol, Plasma NEFA, Serum Trigly- cerides and Serum Cholesterol (Tables 2 and 3)}

Blood glycerol concentration differed significantly during the three regimes $(p<0.001)$. Highest concentrations were found during phenformin and lowest concentrations during glibenclamide therapy. Four patients had lower $12 \mathrm{~h}$ values on glibenclamide than metformin, although in one patient there was a marked increase in blood glycerol concentration with glibenclamide therapy.

There was no significant difference in plasma NEFA concentrations during phenformin and metformin therapy. A significant decrease $(p<0.001)$ was found, however, during glibenclamide therapy (Table 3).

Serum triglycerides were significantly higher during phenformin $(p<0.001)$ than either metformin or glibenclamide therapy (Table 3 ). Serum cholesterol was measured on fasting specimens only, and no significant difference was found between the three drugs.

\section{Serum Insulin and Insulin/Glucose $(I / G)$ Ratio}

Serum insulin concentrations over the $12 \mathrm{~h}$ period were highest on glibenclamide and lowest on phenformin (Table 3). The difference between the three regimes was significant $(p<0.001)$. There was no significant difference, however, between fasting concentrations (Table 2).

The increase in serum insulin concentration following the three meals of the $12 \mathrm{~h}$ was greater with glibenclamide than either of the biguanides and higher concentrations were maintained for longer than with the biguanides. If the individual responses are analysed, however, it can be seen that only three of six patients showed greatly increased concentrations of serum insulin following meals while on glibenclamide; the remaining three patients showing similar responses to meals during all three therapies. This difference in response is reflected in the $12 \mathrm{~h}$ mean values during the different treatments (Tabie 3).

There was a significant increase $(p<0.001)$ in the $\mathrm{I} / \mathrm{G}$ ratio on glibenclamide but no significant difference between the biguanides (Table 3 ).

\section{Serum HGH, Serum Cortisol, Plasma Cyclic 3', $5^{\prime}-A M P$}

Serum HGH concentrations were significantly higher during the $12 \mathrm{~h}$ period on metformin. Lowest concentrations were found during glibenclamide $(\mathrm{p}$ $<0.001$ compared with both biguanides) (Table 3). The difference between serum HGH concentrations during the two biguanides was significant $(0.001<p$ $<0.01$ ). Serum cortisol was measured only at 0830 $\mathrm{h}, 1200 \mathrm{~h}$ and $1800 \mathrm{~h}$. No significant difference was found between the three treatments (Table 2).

In the three patients for whom cyclic $3^{\prime}, 5^{\prime}$-AMP results were obtained during the three therapies there was no significant difference between the biguanide therapies, but a significant $(\mathrm{p}<0.001)$ decrease in plasma cyclic $3^{\prime}, 5^{\prime}$-AMP levels occurred with glibenclamide.

\section{Discussion}

Despite 20 years of biguanide therapy for maturityonset diabetes their mechanism of action remains uncertain. They have been shown to inhibit intestinal absorption of glucose $[1,2]$ and many other nutrients, including amino acids [22], vitamin $B_{12}$ [23] and other hexoses [24]. While animal experiments have shown phenformin to inhibit hepatic gluconeogenesis $[4,5,6,7]$, this is difficult to demonstrate in humans. Indeed, increased glucose turnover [25] and increased peripheral glucose utilisation [3] are two of the major findings reported in man, although these represent isolated reports.

In the present study we have shown a significant increase in circulating concentrations of the gluconeogenic precursors, lactate, pyruvate, alanine, and glycerol, during both biguanide therapies, with higher concentrations being found during phenformin therapy.

Other workers have reported elevated fasting concentrations of lactate and pyruvate during phenformin therapy $[9,26]$, but amounts used were 
greater than in the present study, ranging from 125 $\mathrm{mg}$ to $400 \mathrm{mg}$ per day. Normal fasting concentrations have been reported with doses of phenformin such as those used in the present study in both diabetic [9] and normal subjects [27].

It is of interest that the effects of the two biguanides on intermediary metabolite concentrations were different. The reasons for this are unclear but may well be related to differences in distribution and concentration in tissues. It is clear, however, that for doses of the two drugs which have a similar effect upon blood glucose, greater metabolic abnormality is seen with phenformin than with during metformin.

It follows that the metabolic abnormalities during the biguanide therapies were not simply a consequence of the mild elevation of blood glucose. In addition we have re-studied two of the six patients on diet alone. Blood glucose concentrations remained the same in one and were elevated in the other. The other abnormalities, however, were absent. We have also shown that when biguanide therapy is stopped in patients taking combined sulphonylurea and biguanide therapy, gluconeogenic precursor concentrations fall, although blood glucose concentration rises [28].

Enhanced peripheral utilisation of glucose alone is insufficient to account for the accumulation in the blood of gluconeogenic precursors since increased concentrations were not found when peripheral insulin concentrations were raised with glibenclamide. An increase in concentration of gluconeogenic precursors would occur, however, if hepatic utilisation and/or uptake of these metabolites was impaired, with or without increased extra-hepatic production. This implies that inhibition of hepatic gluconeogenesis must be one of the primary actions, but not necessarily the sole action, of the biguanides.

Inhibition of hepatic gluconeogenesis by biguanides has been well documented in animal experiments. There is however still considerable controversy concerning the mechanism. Suggestions include inhibition of ATP production [5, 29], interference with the transport of reducing equivalents across the mitochondrial membrane [30] and alteration in the nature of the mitochondrial membrane [31]. Some doubt is cast on the ATP hypothesis by the finding that inhibition of gluconeogenesis can occur without any change in total hepatic ATP [30]. We have found increased lactate/pyruvate and 3-hydroxybutyrate/acetoacetate ratios, which give a crude index of the cytosolic and hepatic mitochondrial redox ratio respectively. These findings could be explained by any of these hypotheses.

A significant increase in ketone body concentra- tions was found in our patients on biguanide therapy. This has received scant attention previously although isolated reports of increased ketonaemia have appeared [32, 33] and a small increase in 3 -hydroxybutyrate concentration was noted in patients taking buformin [34]. This could be explained by the more reduced state within the cell. This would lead to an increase in the malate/oxaloacetate ratio with a fall in oxaloacetate concentration. The latter would no longer be available for condensation with acetyl CoA to form citrate and acetyl CoA would be directed into ketone body formation. This hypothesis is supported by the finding of decreased intrahepatic citrate in animal experiments [35]. Others have suggested that enhanced NEFA supply to the liver is responsible for the increased ketogenesis [34], but in our patients there was no significant difference in plasma NEFA concentration during phenformin compared with metformin therapy, while ketonaemia was more marked with phenformin.

The significant increase in glycerol concentrations seen with both biguanides is in agreement with results from perfusion of isolated rat [7] and guinea pig [5] livers. Glycerol enters gluconeogenesis by conversion of glycerol-1-phosphate to dihydroxyacetone phosphate and the equilibrium of this reaction is dependent upon the redox state of the cytosol. An increase in the cytosol NADH/NAD ratio would result in a shift of equilibrium to favour an increase in glycerol-1-phosphate, thus preventing the entry of glycerol into the gluconeogenic pathway. Phenformin has been reported to lower serum triglyceride and NEFA concentrations in diabetic patients $[36,37]$. Since we did not study our patients without drug therapy we are unable to support these findings but, at the least, biguanide therapy did not offer any advantage over glibenclamide therapy in this respect.

In conclusion therefore, we have shown abnormalities in intermediary metabolite concentrations which occurred during therapy with both biguanides, but were more marked during phenformin therapy than during metformin, despite similar blood glucose concentrations. If our aim in treating diabetes is to produce metabolic normality, discretion must be used in the use of drugs which fail this aim.

Acknowledgements. We wish to thank Mr. J. R. Alexander for statistical advice, and Miss P. Smythe, Mr.D. Turnell and Mr. R. Whitefoot for technical help. We would also like to express our gratitude to Sister Smith, and Sisters Spence and Gardner and their staff for their assistance. These studies were supported by the British Diabetic Association and Hoechst Pharmaceuticals Ltd. 


\section{References}

1. Caspary, W.F., Creutzfeldt, W.: Analysis of inhibitory effect of biguanides on glucose absorption: inhibition of active sugar transport. Diabetologia 7, 379-385 (1971)

2. Czyzyk, A., Tawecki, J., Sadowski, J., Ponikowska, I., Szczepanik, Z.: Effect of biguanides on intestinal absorption of glucose. Diabetes 17, 492-498 (1968)

3. Butterfield, W.J.H., Whichelow, M. J.: The hypoglycemic action of phenformin. Effect of phenformin on glucose metabolism in peripheral tissues. Diabetes 11, 281-286 (1962)

4. Meyer, F., Ipaktchi, M., Clauser, H.: Specific inhibition of gluconeogenesis by biguanides. Nature 213, 203-204 (1967)

5. Altschuld, R.A., Kruger, F. A.: Inhibition of hepatic gluconeogenesis in guinea pig by phenformin. Ann. N. Y. Acad. Sci. 148, 612-622 (1968)

6. Cook, D.E., Blair, J.B., Lardy, H.A.: Mode of action of hypoglycaemic agents. V. Studies with phenethylbiguanide in isolated perfused rat liver. J. Biol. Chem. 248, 5272-5277 (1973)

7. Medina, J.M., Sánchez-Medina, F., Mayor, F.: Effect of phenformin on gluconeogenesis in perfused rat liver. Rev. Esp. Fisiol. 27, 253-256 (1971)

8. Varma, S. K., Heaney, S.J., Whyte, W.G., Walker, R.S.: Hyperlactataemia in phenformin-treated diabetics. Br. Med. J. 1972 I, 205-206

9. Craig, J.W., Miller, M., Woodward, H., Merik, E.: Influence of phenethylbiguanide on lactic, pyruvic and citric acids in diabetic patients. Diabetes 9, 186-193 (1960)

10. Debry, G., Anziani, C., Cherrier, P., Laurent, J.: Étude de la lactacidémie à jeun chez les diabétiques traités par le N-Ndiméthylbiguanide. Le Diabete 12, 239-245 (1964)

11. Assan, R., Heuclin, C., Girard, J.R., Lemaire, F., Attali, J. R.: Phenformin-induced lactic acidosis in diabetic patients. Diabetes 24, 791-800 (1975)

12. Ball, S., Woods, H.F., Alberti, K. G. M.M.: Lacticacidosis, ketoacidosis, and hyperalaninaemia in a phenformin-treated diabetic patient. Br. Med. J. 1974 IV, 699-700

13. Cohen, R. D., Woods, H.F.: Clinical and biochemical aspects of lactic acidosis. p. 166. Oxford: Blackwell Scientific Publications 1976

14. Cramp, D. G.: Automated fluorimetric techniques based on NAD- and NADP-linked enzyme systems in the study of intermediary carbohydrate metabolism. J. Med. Lab. Technol. 27, 359-382 (1970)

15. Williamson, D.H., Mellanby, J., Krebs, H. A.: Enzymic determination of $\mathrm{D}(-)-\beta$-hydroxybutyric acid and acetoacetic acid in blood. Biochem. J. 82, 90-96 (1962)

16. Ho, R.J., Meng, H.C.: A simple and ultrasensitive method for determination of free fatty acid by radiochemical assay. Anal. Biochem. 31, 426-436 (1969)

17. Holub, W. R.: Rapid, simplified continuous-flow colorimetry of serum triglycerides. Clin. Chem. 19, 1391-1393 (1973)

18. Pearson, S., Stern, S., McGavack, T.H.: A rapid procedure for the determination of serum cholesterol. J. Clin. Endocrinol. 12, 1245-1246 (1952)

19. Soeldner, J.S., Slone, D.: Critical variables in the radioimmunoassay of serum insulin using the double antibody technic. Diabetes 14, 771-779 (1965)

20. Boden, G., Soeldner, J.S.: A sensitive double antibody radioimmunoassay for human growth hormone (HGH): levels of serum HGH following rapid tolbutamide infusion. Diabetologia 3, 413-421 (1967)

21. Alberti, K. G. M.M., Dornhorst, A., Rowe, A.S.: Metabolic rhythms in normal and diabetic man. Isr. J. Med. Sci. 2, 571-580 (1975)
22. Caspary, W. F., Creutzfeldt, W.: Inhibition of intestinal amino acid transport by blood sugar lowering biguanides. Diabetologia 9, 6-12 (1973)

23. Tomkin, G.H.: Malabsorption of vitamin $B_{12}$ in diabetic patients treated with phenformin: a comparison with metformin. Br. Med. J. 1973 III, 673-675

24. Creutzfeldt, W., Willms, B., Caspary, W.: The mechanism of action of the blood glucose lowering biguanides. In: Diabetes. Proceedings of the VII ${ }^{\text {th }}$ Congress of the International Diabetes Federation. Buenos Aires, 1970 (eds. R. R. Rodriguez, J. Vallance-Owen), pp. 708-719. Amsterdam: Excerpta Medica 1971

25. Searle, G. L., Schilling, S., Porte, D., Barbaccia, J., De Grazia, J., Cavalieri, R. R.: Body glucose kinetics in nondiabetic human subjects after phenethylbiguanide. Diabetes 15, 173-178 (1966)

26. Fajans, S. S., Moorhouse, J. A., Doorenbos, H., Louis, L.H., Conn, J. W.: Metabolic effects of phenethylbiguanide in normal subjects and in diabetic patients. Diabetes 9, 194-201 (1960)

27. Lyngsoe, J., Bitsch, V., Trap-Jensen, J.: Influence of phenformin on fat and lactate metabolism and insulin production in starved normal subjects. Metabolism 21, 179-186 (1972)

28. Nattrass, M., Lloyd, B., Todd, P.G.: Metabolic effects of combined sulphonylurea and biguanide therapy. Diabetologia 12, (Abstr.) 411 (1976)

29. Ogata, K., Jomain-Baum, M., Hanson, R. W.: Phenethylbiguanide and the inhibition of hepatic gluconeogenesis in the guinea pig. Biochem. J. 144, 49-57 (1974)

30. Toews, C. J.: USV Workshop Discussion: metabolic effects of biguanides, p. 29. Paris, 1975

31. Schäfer, G.: Some new aspects on the interaction of hypoglycemia-producing biguanides with biological membranes. Biochem. Pharmacol. 25, 2015-2024 (1976)

32. Walker, R.S., Linton, A. L.: Phenethylbiguanide: a dangerous side effect. Br. Med. J. 1959 II, 1005-1006

33. Wildenhoff, K.E.: The influence of diabetic regulation on the diurnal variation in blood and the urinary excretion of ketone bodies. Acta. Med. Scand. 198, 127-133 (1975)

34. Kattermann, R., Appels, A., Hubrich, K., Proschek, H., Söling, H.D., Creutzfeldt, W.: Untersuchungen über die Wirkung von Diät, Tolbutamid und Buformin sowie deren Kombination auf Körpergewicht und verschiedene Stoffwechselgrößen bei Diabetikern. II. Freie Fettsäuren, Ketonkörper, Triglyceride und Cholesterin im Blut. Diabetologia 4, 221-228 (1968)

35. Alberti, K. G. M. M., Holloway, P.A.H., Johnson, G., Man, K. C., Nattrass, M.: Biguanides and ketone body metabolism in animals and man. In: Biochemical and clinical aspects of ketone body metabolism (ed. H.D. Söling), Stuttgart: Georg Thieme Verlag 1977

36. Alterman, S. L., Lopez-Gomez, A. A.: Phenformin effect on body weight lipids, and glucose regulation. Ann. N. Y. Acad. Sci. 148, 884-891 (1968)

37. Mirsky, S.: Influence of hypoglycemic therapy on blood lipids and body weight in diabetes mellitus. Ann. N. Y. Acad. Sci. 148, 937-944 (1968)

Received: October 6, 1976, and in revised form: January 3, 1977

Prof. K. G. M. M. Alberti

Chemical Pathology and Human Metabolism

South Laboratory and Pathology Block

Level D

Southampton General Hospital

Tremona Road

Southampton S09 4XY

U. K. 